\title{
Study of the Process of Electro Evolution of Copper lons from Waste Regeneration Solutions
}

\author{
Ganna Trokhymenko', Nataliya Magas' ${ }^{1}$ Nikolai Gomelya², \\ Inna Trus ${ }^{2}$, Anastasiia Koliehova ${ }^{1 *}$ \\ 1 Admiral Makarov National University of Shipbuilding, 54025, Heroiv Ukrainy ave., 9,Mykolaiv, Ukraine \\ 2 National Technical University of Ukraine «lgor Sikorsky Kyiv Polytechnic Institute», 03056, Peremohy ave., 37, \\ Kyiv, Ukraine \\ * Corresponding author's e-mail: nastya.sukhareva92@gmail.com
}

\begin{abstract}
The article presents the results of the study on the process of copper electroevolution from the regeneration solutions in one- and two-chamber electrolyzers at different concentrations of sulfuric acid and the solutions of copper chlorides at different concentrations of hydrochloric acid - in a three-chamber electrolyzer. The conditions of electrochemical recovery of heavy metals from acidic and saline solutions were determined. It was shown that the most effective recovery of heavy metal cations from hydrochloric acid solutions occurs in three-chamber electrolyzers. On the basis of the results obtained, a technological scheme of a local plant for treatment of washing water of galvanic industries was proposed.
\end{abstract}

Keywords: heavy metals, electrochemical methods, chemical reagents, wastewater treatment

\section{INTRODUCTION}

Electrochemical methods are often used to treat wastewater; they are the alternative to the ion exchange and reagent treatment methods. They enable to obtain valuable products through relatively simple purification technologic schemes, without the use of expensive and scarce chemical reagents. The electrochemical wastewater treatment is based on the processes of anodic oxidation and cathodic reduction, electro-flocculation, electro-coagulation and electro-dialysis. One of the major disadvantages of these methods is the high electric power consumption.

Electrodialysis on ion-exchange membranes is one of the most effective and environmentally friendly methods of natural waters desalination, wastewater treatment, obtaining of ultra-pure water, separation of electrolytes and non-electrolytes. Its disadvantage is the concentration polarization, which limits the current density [Mulder 1996].

For the processing of waste regeneration solutions, electrodialysis is used mainly to form acids and alkalis of saline solutions. [Goncharuk 2005; Ayala-Bribiesca 2007; Chkhenadze 2004]. However, acidic solutions of salts are formed in acidic cationite regeneration and basic solutions of salts are created in anionite regeneration; these salts can complicate the electrodialysis process. The efficiency of electrolysis of acidic or alkaline regeneration solutions, compared with neutral ones, in two-, three- and four-chamber electrolyzers was assessed in papers [Shabliy et al. 2010(1); Shabliy et al. 2010(2); Shabliy 2010; Goltvianytska et al. 2011; Shabliy et al. 2011].

There are several technologies for the separation of the sulfuric acid from the waste regeneration solutions of $\mathrm{H}$-ionite filters and their subsequent use for the regeneration of the same filters [Rohm et al. 2000; Ivakina et al. 1976; Hodges et al. 2001; Teel 2004; Feyziev 1988; Dzhalilov 1987; Faiziiev et al. 1991].

The author [Obertas 2016] proposes a method for electrochemical purification of water of the pollutants, which are able to coagulate impurities due to the formation of closed galvanic pairs 
between them, by filtration through loading with reductive-oxidative properties. The mechanisms of active dissolution of metal and the influence of these processes on water purification were shown.

In the paper [Skira et al. 2004], the regularity of iron oxidation in electrolyzers with different types of electrodes (flat and sharp) in a horizontal position at different voltage was studied. The results showed that the effect of oxidation changes significantly in the electrolyzer with a sharp anode and tends to lowerat the decreasing distance between the electrodes. Therefore, better oxidation conditions are provided in a electrolyzer with flat electrodes located at the distance of $0.04-0.05 \mathrm{~m}$. At longer distances, resistance increases and electricity is converted to heat.

In the paper [Fylypchuk et al. 2014], the principle of action and processes that occur during the operation of the plants for electrochemical waste water treatment using soluble and insoluble electrodes were described. The hazardous factors arising from the operation of the plants and measures and agents for their safe operation were also analyzed.

The authors of the papers [Bairachnyi et al. 2012; Melnyk et al.] presented a method for extracting the metal ions from waste biologically active water medium by passing through sorbents. In the paper [Bairachnyi et al. 2012], the prestage of electrochemical recovery of metal ions was carried out, which envisaged the extraction of copper ions to the concentration of $60 \mathrm{mg} / \mathrm{dm}^{3}$ with subsequent cation-exchange treatment to the values of maximum permissible concentrations (MPC) as well as extraction of silver ions to the concentration of $4.5 \mathrm{mg} / \mathrm{dm}^{3}$ with subsequent cation-exchange treatment to the values of maximum permissible concentrations (MPC). The parameters and results obtained are the basis for the development of technologies for the electro-chemical extraction of copper and silver from technological solutions for decontamination of municipal water-circulation closed systems.

The treatment of galvanic wastewater by galvanic coagulation on the example of wastewater treatment containing chromium (VI) was proposed in the paper [Vasylenko et al. 2014]. The water stream to be purified is passed through a filter consisting of a porous cathode (activated carbon) and magnesium anode. As water passes through the porous loading, the particles of the anode substance - magnesium - come into contact with the surface of the activated carbon and discharge on it, and the electrochemical oxidation of magnesium occurs. At the same time, the cations of chromium in the solution move to the cathode and discharge on it. The efficiency of the wastewater treatment with use of the method proposed reaches $98-99 \%$.

It is known that the ions of heavy metals such as copper, cadmium, lead and other next to hydrogen in activity line are easily recovered electrochemically, even from acidic solutions. Metals such as zinc and nickel are recovered from acidic solutions only at high concentrations (higher than $90-100 \mathrm{~g} / \mathrm{dm}^{3}$ ). If zinc is easily recovered in a neutral medium, then nickel is recovered only in weakly acidic medium $(\mathrm{pH}=3-4)$ with high current efficiency [Grytsenko et al. 2016]. Therefore, the choice of conditions for the effective removal of metals from waste regeneration solutions by electro-extraction is an important and urgent concern.

The objective of this work was to investigate the process of electro evelution of copper from regeneration solutions in electrolyzers of different models.

\section{MATERIALS AND METHODS}

The authors used one-, two- and three-chamber electrolyzers for the process of electrodialysis (Fig. 1, 2, 3).

In the electrolysis processes, a $100 \mathrm{~cm}^{3}$ cell in one-chamber electrolyzers was employed. A 12Cr18Ni10Ti stainless steel plate was used as the cathode, and a ruthenium oxide coated titanium plate was used as the anode. The area of the electrodes $\mathrm{SK}=\mathrm{SA}=0.12 \mathrm{dm}^{2}$. The electrolysis was carried out at a current density of $1-10 \mathrm{~A} / \mathrm{dm}^{2}$ at a voltage of 5-50 V.

In one-chamber electrolyzers, the electro extraction of metals from copper sulfate solutions was carried out at different concentrations of sulfuric acid. The process was performed by keeping the voltage at $5 \mathrm{~V}$ and recording the change in current over time, or by maintaining constant values of the current due to voltage regulation. The voltage was also monitored in the course of the electrolysis.

In addition to the current and voltage, the residual metal content and acidity of the solution were monitored at regular intervals (15-60 minutes).

The electrolysis of copper sulfate solutions with different acidity of the solutions was carried 


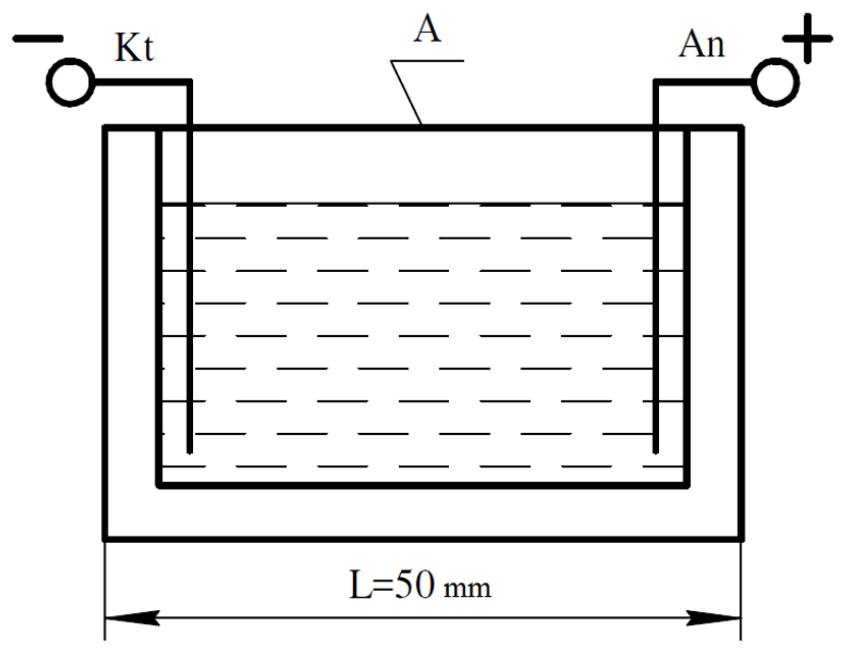

Figure 1. One-chamber electrolyzer: $\mathrm{Ct}$ - cathode of $12 \mathrm{Cr} 18 \mathrm{Ni10 \textrm {Ti }}$ stainless steel; An - ruthenium oxide coated titanium anode

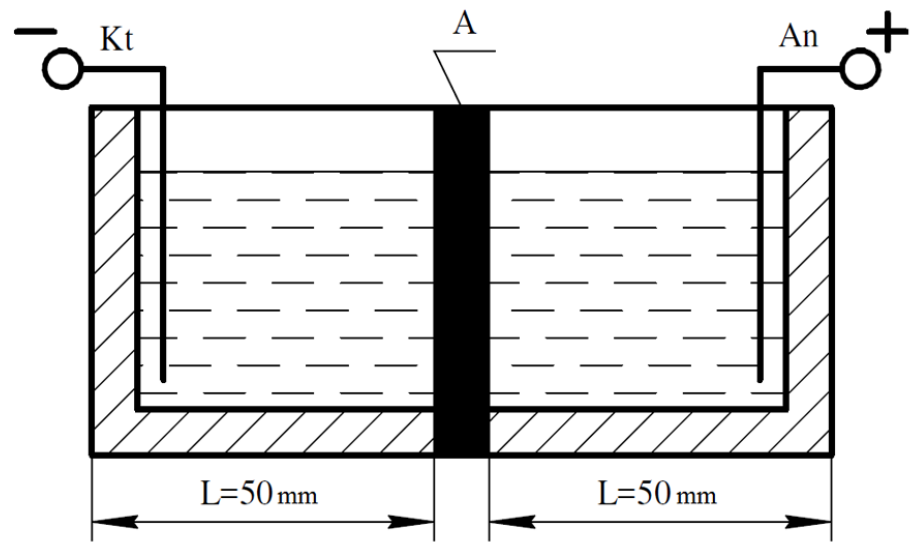

Figure 2. Two-chamber electrolyzer: $\mathrm{Ct}$ - cathode of $12 \mathrm{Cr} 18 \mathrm{Ni10Ti}$ stainless steel; $\mathrm{An}$ - ruthenium oxide coated titanium anode; A - anion-exchange membrane MA-41

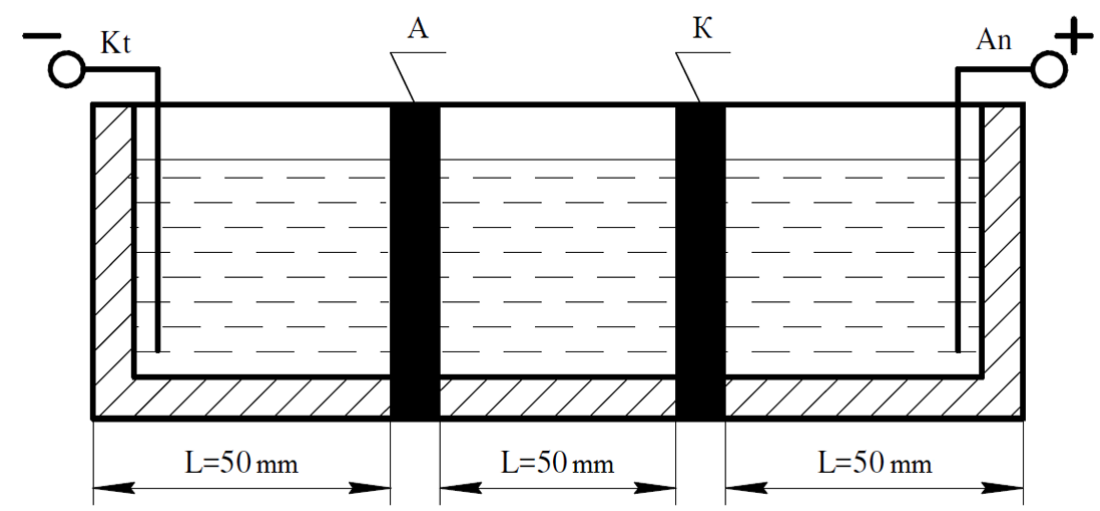

Figure 3. Three-chamber electrolyzer: $\mathrm{Ct}$ - cathode of $12 \mathrm{Cr} 18 \mathrm{Ni} 10 \mathrm{Ti}$ stainless steel; $\mathrm{An}$ - titanium anode ruthenium oxide coated; A - anion-exchange membrane MA-41; C - cation exchange membrane MK-40 
out in two-chamber electrolyzers. The acidity was adjusted with sulfuric acid. The working solutions containing metal ions were placed in the cathode region. A $0.05 \mathrm{~N}$ solution of sulfuric acid was placed in the anode chamber to provide electrical conductivity. The volume of the cathode and anode chambers was $175 \mathrm{~cm}^{3}$.

The electrolysis was carried out at a voltage of $25 \mathrm{~V}$ with constant control of the current. In addition, the concentration of metal and acidity in the catholyte was monitored, the acidity in the anolyte was monitored with the same periodicity.

The electrolysis of copper chlorides was carried out in three-chamber electrolyzers. The acidity of the solutions was adjusted with hydrochloric acid.

The working solutions were placed in the cathode region, a $0.05 \mathrm{~N}$ solution of sulfuric acid was placed in the anode region, a $0.05 \mathrm{~N}$ solution of hydrochloric acid was placed in the middle chamber. The electrolysis was carried out at a voltage of $20 \mathrm{~V}$ at a constant density of the current. In addition, the residual metal content and the acidity in the catholyte, in the middle the chamber, and anolyte were determined every 30 minutes.

The degree of removal of the metals from the acidic solutions was calculated by means of the formula:

$$
Z=\left(\frac{C_{i}-\mathrm{C}_{r}}{\mathrm{C}_{i}}\right) \cdot 100 \%
$$

where: $C_{i}$ - initial metal concentration, $\mathrm{mg} / \mathrm{dm}^{3}$; $C_{r}$-residual metal concentration, $\mathrm{mg} / \mathrm{dm}^{3}$.

Current efficiency (E, \%) was calculated as the ratio of the actual amount of recovered metal to the theoretically possible amount calculated with Faraday's law:

$$
\mathrm{E}=\frac{m_{r}}{m_{t}} \cdot 100 \%
$$

where: $m_{r}$ - the real amount of the recovered metal, mg-eq;

$m_{t}-$ the real amount of recovered metal.

The amount of metal recovered for time $t$ was calculated by means of the formula:

$$
m_{P}=\left(C_{i}-\mathrm{C}_{r}\right) \cdot V_{P}, \text { mg-eq }
$$

where: $C_{i}$ - concentration of the metal in solution before electrolysis;
$C_{r}$ - the residual concentration of the metal in the solution after electrolysis for time $t$.

The theoretically calculated quantity of metal was determined with the formula:

$$
m_{T}=\frac{1}{F} \cdot I \cdot t, \mathrm{mg} \text {-eq }
$$

where $F$-Faraday's constant,

$I$ - current,

$t$ - time, hour.

\section{RESULTS AND DISCUSSION}

The authors conducted a number of studies on the selection of copper in one-, two- and threechamber electrolyzers.

Acidic solutions of copper sulfate were used in the electrochemical reduction of copper. More specifically, the solutions containing $11.826 \mathrm{~g} / \mathrm{dm}^{3}$ of copper ions and 204, 320 or $612 \mathrm{mg}$-eq/$/ \mathrm{dm}^{3}$ of sulfuric acid were employed. The electrolysis was carried out at a voltage of $5 \mathrm{~V}$ (Table 1). The electrolysis time was 6 hours. During this time, the copper concentration decreased to $5-7 \mathrm{mg} / \mathrm{dm}^{3}$, and the acidity increased (depending on the initial acid content) to $575-976 \mathrm{mg}$-eq $/ \mathrm{dm}^{3}$ $(2.8-4.8 \%)$. These concentrations were sufficient to reuse the resulting acid to further regeneration of the cationites.

More complicated is the problem of processing a solution containing a mixture of copper sulfate and sodium sulfate, which are formed during the regeneration of the ionite with sodium sulfate in the process of ion exchange. When using one-chamber electrolyzer, a mixture of sodium sulfate and sulfuric acid with traces of copper is received. This solution should be postneutralized when reused. However, when using a two-chamber electrolyzer, this problem is solved.

When a solution of copper sulfate and sodium sulfate is placed in the cathode region and a weak solution of sulfuric acid is placed in the anode region, accumulation of a solution of sulfuric acid occurs as a result of electrolysis of the production of copper as a powder in the anode region. The efficiency of the process (Table 2) depends on both the concentration of copper ions in the regeneration solution and the acidity in the anode region.

Generally, as a result of the electrolysis, the concentration of copper ions in the solutions of 
Table 1. The influence of electrolysis time on the efficiency of recovery of copper ions from acidic solutions of copper sulfate at a voltage of $5 \mathrm{~V}^{*}$ in one-chamber electrolyzer

\begin{tabular}{|c|c|c|c|c|c|c|c|c|c|c|c|c|}
\hline \multirow{2}{*}{$\mathrm{t}, \min$} & \multicolumn{3}{|c|}{$\mathrm{I}, \mathrm{A}$} & \multicolumn{3}{|c|}{$\mathrm{C}_{\mathrm{Cu}}^{2+}, \mathrm{mg} / \mathrm{dm}^{3}$} & \multicolumn{3}{|c|}{ A, mg-eq/dm ${ }^{3}$} & \multicolumn{3}{|c|}{ E, \% } \\
\hline & I & II & III & I & II & III & I & II & III & I & II & III \\
\hline 0 & - & - & - & 11826.0 & 11826.0 & 11826.0 & 204 & 320 & 612 & - & - & - \\
\hline 60 & 0.482 & 0.490 & 0.510 & 8304.0 & 8505.0 & 8610.0 & 315 & 424 & 713 & 64.0 & 57.1 & 53.1 \\
\hline 120 & 0.490 & 0.495 & 0.515 & 4582.1 & 4674.0 & 4714.1 & 432 & 547 & 835 & 65.2 & 65.9 & 63.5 \\
\hline 180 & 0.491 & 0.489 & 0.497 & 1260.7 & 1370.1 & 1520.4 & 537 & 647 & 936 & 57.1 & 56.9 & 54.1 \\
\hline 240 & 0.178 & 0.185 & 0.193 & 201.3 & 332.0 & 450.2 & 571 & 680 & 970 & 50.2 & 47.4 & 46.7 \\
\hline 300 & 0.061 & 0.057 & 0.075 & 59.4 & 50.6 & 120.3 & 574 & 681 & 975 & 39.7 & 41.3 & 37.1 \\
\hline 360 & 0.031 & 0.021 & 0.042 & 21.3 & 21.2 & 60.1 & 575 & 681 & 974 & 10.2 & 12.0 & 12.2 \\
\hline 420 & 0.022 & 0.015 & 0.030 & 6.7 & 6.4 & 12.4 & 575 & 682 & 975 & 5.8 & 8.8 & 7.2 \\
\hline
\end{tabular}

* I - the acidity of the initial solution $204 \mathrm{mg}-\mathrm{eq} / \mathrm{dm}^{3}$;

II - the acidity of the initial solution $320 \mathrm{mg}-\mathrm{eq} / \mathrm{dm}^{3}$;

III - the acidity of the initial solution $612 \mathrm{mg}-\mathrm{eq} / \mathrm{dm}^{3}$.

sodium sulfate was reduced to $0.9-4 \mathrm{mg} / \mathrm{dm}^{3}$. The reuse of such solutions for cationite regeneration is as effective as that of pure sodium sulfate solutions. The highest recovery efficiency of copper was observed in the first 3-4 hours, when the copper concentration was high. As the copper concentration in the cathode region decreases and the acidity in the anode region increases, the resistance of the system increases and the current efficiency drops accordingly. As the initial acid concentration in the anode region increases, both the recovery rate of copper and its current efficiency decrease. This is still explained by the increasing resistance of the system. A similar trend was observed in the electrolysis of acidic solutions. However, in that case, the process went because of the lack of a membrane at lower voltage. For the same reason, the copper current efficiency was significantly below - at 54-65\% versus $89-99 \%$ - when using the membrane. The main result of using two-chamber electrolyzer is obtaining a purified solution of sodium sulphate, reusable, and a solution of sulfuric acid as a by-product.
Using the data from the complete factorial experiment, the authors obtained the regression equation for the processes of electro-extraction of copper ions in a two-chamber electrolyzer, depending on the acidity of the anolyte and the time of electrolysis.

The equation obtained in the extraction of copper has the following form:

$$
\begin{gathered}
y=\exp (9,7467-1,2375 \cdot \tau+ \\
+0,0002451 \cdot \mathrm{K}+0,00001812 \cdot \mathrm{K} \cdot \tau)
\end{gathered}
$$

A graphic imaging of the concentration of copper ions on the acidity and time of the electrolysis is represented in Figure 4.

As can be seen in Figure 4, the concentration of copper in the electrolyte decreases with time of the electrolysis and more effectively it decreases with less acidity in the anolyte, which is caused by the increase of the system resistance along with acidity of the anolyte.

As a result of studying the efficiency of cationite regeneration from heavy metal ions, it can be seen

Table 2. The dependence of the efficiency of recovery of copper ions in a two-chamber cell (anion membrane MA-41) on the time of electrolysis and acidity in the anode region at a voltage of $25 \mathrm{~V}$

\begin{tabular}{|c|c|c|c|c|c|c|c|c|c|c|c|c|}
\hline \multirow{2}{*}{$\mathrm{t}, \min$} & \multicolumn{3}{|c|}{$\mathrm{I}, \mathrm{A}$} & \multicolumn{3}{c|}{$\mathrm{C}_{\mathrm{Cu}}{ }^{2+}, \mathrm{mg} / \mathrm{dm}^{3}$} & \multicolumn{3}{c|}{$\mathrm{A}, \mathrm{mg}-\mathrm{eq} / \mathrm{dm}^{3}$} & \multicolumn{3}{c|}{$\mathrm{E}, \%$} \\
\cline { 2 - 16 } & $\mathrm{I}$ & $\mathrm{II}$ & $\mathrm{III}$ & $\mathrm{I}$ & $\mathrm{II}$ & $\mathrm{III}$ & $\mathrm{I}$ & $\mathrm{II}$ & $\mathrm{III}$ & $\mathrm{I}$ & $\mathrm{II}$ & $\mathrm{III}$ \\
\hline 0 & - & - & - & 13778.0 & 13778.0 & 13778.0 & 52.0 & 280.0 & 540.0 & - & - & - \\
\hline 60 & 0.384 & 0.390 & 0.400 & 9278.0 & 9281.0 & 9291.0 & 143.8 & 371.8 & 631.6 & 98.68 & 97.12 & 94.95 \\
\hline 120 & 0.385 & 0.395 & 0.401 & 4722.0 & 4746.0 & 4754.3 & 236.8 & 464.3 & 724.2 & 99.69 & 96.69 & 95.32 \\
\hline 180 & 0.382 & 0.387 & 0.398 & 202.6 & 230.5 & 520.1 & 329.0 & 556.5 & 810.4 & 99.54 & 99.45 & 89.51 \\
\hline 240 & 0.012 & 0.020 & 0.045 & 58.3 & 59.7 & 104.1 & 332.0 & 560.0 & 818.9 & 93.40 & 74.35 & 77.04 \\
\hline 300 & 0.005 & 0.019 & 0.022 & 22.0 & 29.6 & 62.7 & 332.7 & 560.4 & 819.7 & 54.68 & 13.63 & 15.76 \\
\hline 360 & 0.004 & 0.018 & 0.016 & 11.4 & 9.2 & 18.31 & 333.0 & 560.5 & 820.6 & 21.62 & 10.05 & 14.42 \\
\hline 420 & 0.003 & 0.016 & 0.015 & 5.6 & 5.9 & 8.21 & 333.1 & 560.7 & 820.9 & 16.29 & 1.58 & 5.01 \\
\hline 480 & 0.003 & 0.014 & 0.013 & 0.9 & 4.6 & 2.05 & 333.2 & 560.8 & 820.7 & 13.20 & 0.76 & 3.75 \\
\hline
\end{tabular}




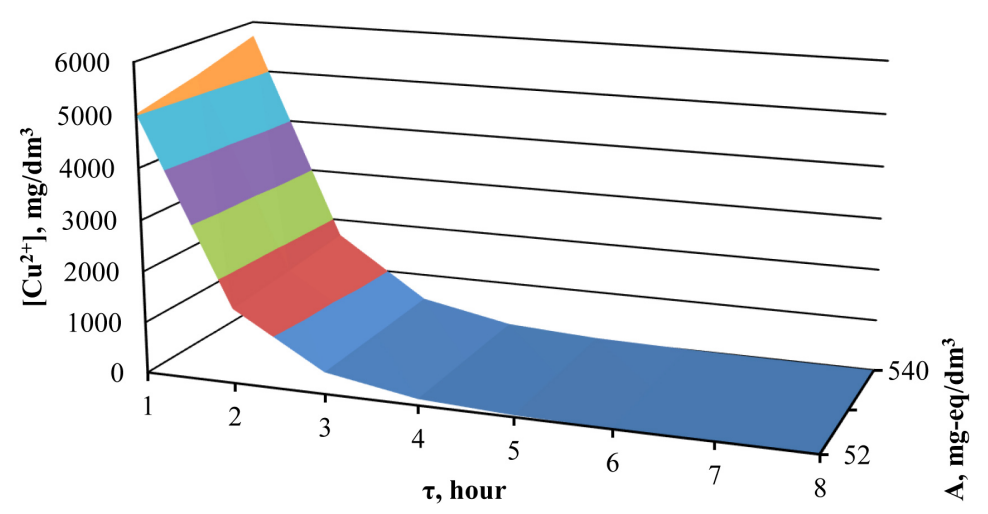

Figure 4. Graphic imaging of the outcome of $2^{2}$ type CFE at copper electroextraction in two-chamber electrolyzer

that hydrochloric acid provides higher desorption efficiency for metal ions in comparison with sulfuric acid. However, the main disadvantage of hydrochloric acid is the complexity of processing waste regeneration solutions. In the presence of chlorides, electrodes are rapidly destroyed in the process of electrochemical recovery of heavy metals. In addition, active chlorine releases on the anode.

In the conducted studies, the authors first used a three-chamber electrolyzer with ruthenium oxide coated titanium anode and a stainless steel cathode. The anode region was separated by the MK-40cathode membrane, the cathode region was separated by the MA-41 anionic membrane. The working solutions with heavy metal chlorides were placed in the cathode region, solution of sulfuric acid was placed in the anode chamber, while a weak solution of hydrochloric acid was placed in the middle chamber. In the terms of such electrolyzer, the recovery of the metals occurred in the cathode chamber, oxygen released and protons formed in the anode chamber, hydrochloric acid concentrated in the middle chamber due to the diffusion of chloride anions from the cathode region and protons from the anode region.

The results of the copper ions recovery in the three-chamber electrolyzer are shown in Figure 5.

It is known that copper is easily separated from aqueous solutions in the process of electrolysis, since the influence of the competitive process of hydrogen evolution on the cathode is relatively low. As can be seen in Figure 5, better results of copper separation were obtained by increasing the concentration of hydrochloric acid in chamber (II) from 75 to $2750 \mathrm{mg}$-eq/ $/ \mathrm{dm}^{3}$. The most effective copper separation occurred at low concentrations of hydrochloric acid. As the initial $\mathrm{HCl}$ concentration increased, there was a slight decrease in the copper current efficiency. However, within 6 hours of the electrolysis, the authors suceeded in reducing the concentration of copper ions from $944 \mathrm{mg}-\mathrm{eq} / \mathrm{dm}^{3}$ to $25.984-51.97 \mathrm{mg}-\mathrm{eq} / \mathrm{dm}^{3}$ in almost all cases. It is obvious that the concentration of $\mathrm{HCl}$ affects both the efficiency of copper extraction and the acid concentration process.

It should be noted that the electrolysis process was performed by changing the solutions in the cathode chamber while extracting copper without replacing the solutions of hydrochloric acid in the chamber (II). However, if for the first cycle the concentration of $\mathrm{HCl}$ in the chamber (II) increased from 75 to $1620 \mathrm{mg}$-eq $/ \mathrm{dm}^{3}$ (by 1545 $\mathrm{mg}-\mathrm{eq} / \mathrm{dm}^{3}$ ), in the second stage it increased by $1360 \mathrm{mg}-\mathrm{eq} / \mathrm{dm}^{3}$ and reached $3165 \mathrm{mg}$-eq $/ \mathrm{dm}^{3}$; in the third stage, the increase in acid concentration was only $599 \mathrm{mg}-\mathrm{eq} / \mathrm{dm}^{3}$. The acid concentration reached only $3579 \mathrm{mg}-\mathrm{eq} / \mathrm{dm}^{3}(13 \%)$.

The concentrating of the acid in chamber (II) occurred due to both copper chloride using and excess hydrochloric acid. In the process of electrolysis, in the recovery of copper cations and hydrogen ions, a extra-equivalent amount of chlorides from the cathode chamber through the anion membrane migrates towards the anode - chamber (II). The excess of protons formed in the anode chamber upon the release of oxygen moves through the cationic membrane toward the cathode, i.e. into chamber (II), where hydrochloric acid is accumulated. Further migration of chlorides toward the anode and protons toward the cathode is limited by the cationic and anionic membranes, respectively. This promotes the increase in the concentration 


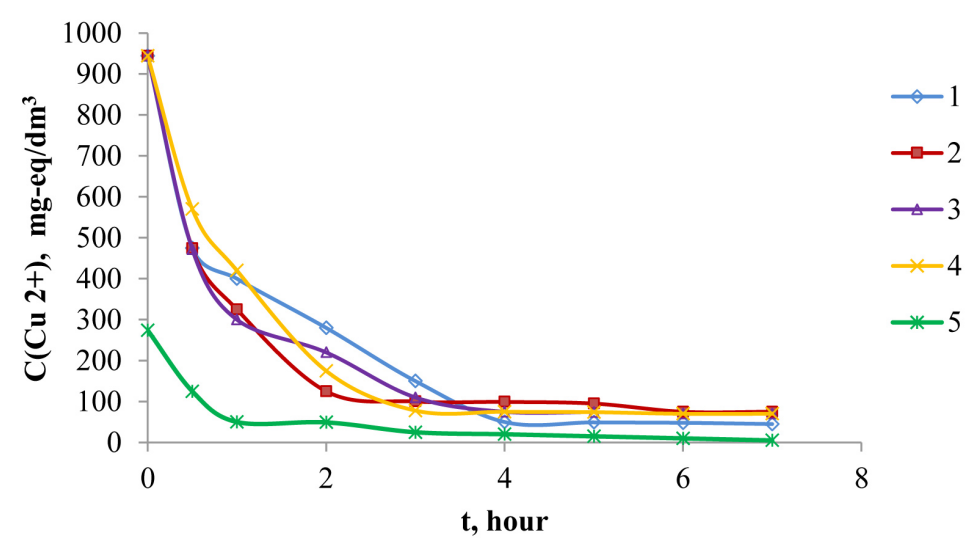

Figure 5. Dependence of the residual concentration of copper ions in the cathode region on the time of copper chloride electrolysis in a three-chamber electrolyzer $(\mathrm{U}=20 \mathrm{~V})$ at the initial concentrations of copper ions $944 \mathrm{mg}$-eq $/ \mathrm{dm}^{3}(1 ; 2 ; 3 ; 4) ; 274 \mathrm{mg}$-eq $/ \mathrm{dm}^{3}$ (5) and hydrochloric acid $750 \mathrm{mg}$-eq $/ \mathrm{dm}^{3}(1), 1100 \mathrm{mg}$-eq $/ \mathrm{dm}^{3}(2)$,

$1911 \mathrm{mg}-\mathrm{eq} / \mathrm{dm}^{3}$ (3), $2750 \mathrm{mg}$-eq $/ \mathrm{dm}^{3}$ (4) ), $70 \mathrm{mg}-\mathrm{eq} / \mathrm{dm}^{3}(5)$

of hydrochloric acid in chamber (II), as well as the electrochemical resistance of the system, which is the reason for limiting the permissible concentrations of $\mathrm{HCl}$ in chamber (II).

Further increase of the initial concentration of hydrochloric acid to $2750 \mathrm{mg}$-eq $/ \mathrm{dm}^{3}$ did not lead to a significant accumulation of the acid in chamber (II). In this case, after 6 hours of electrolysis, the concentration of hydrochloric acid increased only by $300 \mathrm{mg}$-eq $/ \mathrm{dm}^{3}$. At low concentrations of copper chloride (II) and hydrochloric acid following 6 hours of the electrolysis, a decrease in the concentration of copper to $40 \mathrm{mg}$-eq/ $\mathrm{dm}^{3}$ was achieved, while the concentration of hydrochloric acid increased by $535 \mathrm{mg}$-eq $/ \mathrm{dm}^{3}$ only (curve 5).

The dependence of the copper current efficiency on the concentration of hydrochloric acid is complex (Fig. 6). However, the total current efficiency decreased both with the increasing acidity in the initial solutions and in chamber (II).

By reference to the quoted result and literature data analysis, the basic technological schemes of purification of water from heavy metal ions were developed. In the case of the treatment of the galvanic industries wastewater containing metal cations, and solutions of sulfates of these metals used as the electrolytes, it is advisable to use local plants for washing water purification, the technological scheme of which is shown in Fig. 7.

This technological scheme implies the removal of heavy metal cations from water by concentrating them on cationite, followed by the electrochemical reduction to a metallic state in two-chamber electrolyzer.

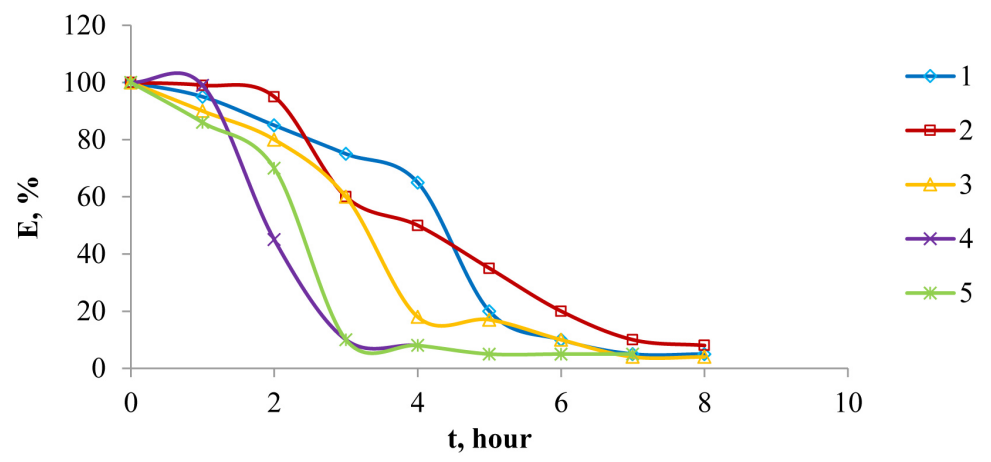

Figure 6. Dependence of the copper current efficiency on the time of electrolysis of the copper chloride solution in three-chamber electrolyzer $(\mathrm{U}=20 \mathrm{~V})$ :

$$
\begin{gathered}
1-\mathrm{C}\left(\mathrm{Cu}^{2+}\right)_{\text {init }}=944 \mathrm{mg}-\mathrm{eq} / \mathrm{dm}^{3}, \mathrm{C}(\mathrm{HCl})_{\text {init }}=75 \mathrm{mg}-\mathrm{eq} / \mathrm{dm}^{3} ; \\
2-\mathrm{C}\left(\mathrm{Cu}^{2+}\right)_{\text {init }}=944 \mathrm{mg}-\mathrm{eq} / \mathrm{dm}^{3}, \mathrm{C}(\mathrm{HCl})_{\text {init }}=1100 \mathrm{mg}-\mathrm{eq} / \mathrm{dm}^{3} ; \\
3-\mathrm{C}\left(\mathrm{Cu}^{2+}\right)_{\text {init }}=944 \mathrm{mg}-\mathrm{eq} / \mathrm{dm}^{3}, \mathrm{C}(\mathrm{HCl})_{\text {init }}=1911 \mathrm{mg}-\mathrm{eq} / \mathrm{dm}^{3} ; \\
4-\mathrm{C}\left(\mathrm{Cu}^{2+}\right)_{\text {init }}=944 \mathrm{mg}-\mathrm{eq} / \mathrm{dm}^{3}, \mathrm{C}(\mathrm{HCl})_{\text {init }}=2750 \mathrm{mg}-\mathrm{eq} / \mathrm{dm}^{3} ; \\
5-\mathrm{C}\left(\mathrm{Cu}^{2+}\right)_{\text {init }}=274 \mathrm{mg}-\mathrm{eq} / \mathrm{dm}^{3}, \mathrm{C}(\mathrm{HCl})_{\text {init }}=70 \mathrm{mg}-\mathrm{eq} / \mathrm{dm}^{3}
\end{gathered}
$$


In this case, the water from the parts washing bath consistently passes two cationic filters (4 and 8) filled with $\mathrm{KU}-2-8$ cationite in the $\mathrm{Na}^{+}$ form. When the washing water contains heavy metal sulfates, heavy metal ions are retained on the cationite and sodium sulfate remains in the water. At its concentrations up to $500-700 \mathrm{mg} /$ $\mathrm{dm}^{3}$, water can be reused for the parts washing. In order to prevent salinization, a portion of the purified water is desalinated on a reverse osmosis filter (12). At a concentration of copper in the washing water at the level of $10 \mathrm{mg} / \mathrm{dm}^{3}$ as a result of a single filter cycle only $0.29 \%$ of the volume of the wash water should be desalinated. Therefore, it is advisable to switch the reverse osmosis filter periodically as the washing water mineralization increases. The reverse osmosis concentrate will contain sodium sulfate. It should mainly be applied to compensate for the loss of sodium sulfate solution at cationite regeneration and electrolytic purification.

The regeneration of cationite in the $1^{\text {st }}$ stage filter is performed after a decrease in the concentration of heavy metal ions at the level of $10 \mathrm{mg} / \mathrm{dm}^{3}$. After regeneration, the $1^{\text {st }}$ stage filter is used to after-purification of the water in the second stage, and the $2^{\text {nd }}$ stage filter is used in the first - the main stage of purification of water from copper ions.

When excess concentrate containing sodium sulfate is formed, it can be electrochemically processed into alkali and sulfuric acid [Trus et al. 2013(1); Trus et al. 2013(2)].
With the same method, it is possible to concentrate the sulfuric acid formed during the recovery of the regeneration solutions in electrolyzer 14. Generally, these methods of the salts processing allow to obtain sulfuric acid and alkali with a concentration up to $40 \%$, which allows them to be used as chemical reagents.

\section{CONCLUSION}

1. The processes of electrolytic extraction of copper from the solutions obtained after the regeneration of ionites used in ion-exchange purification of water contaminated with copper ions were studied. Electroextraction of metal from solutions of copper sulfates in one- and two-chamber electrolyzers at different concentrations of sulfuric acid and from solutions of copper chlorides at different concentrations of hydrochloric acid in a threechamber electrolyzer was carried out.

2. The dependence of the residual concentration of copper ions on the acidity and time of electrolysis was shown. The conditions of electrochemical recovery of heavy metals from acidic and saline solutions were determined. The parameters pertaining to the extraction processes of metals from the solutions of their mixtures and conditions of the separation of metals by regulating the acidity of solutions were established. It was shown that the use of three-chamber electrolyzers provides an

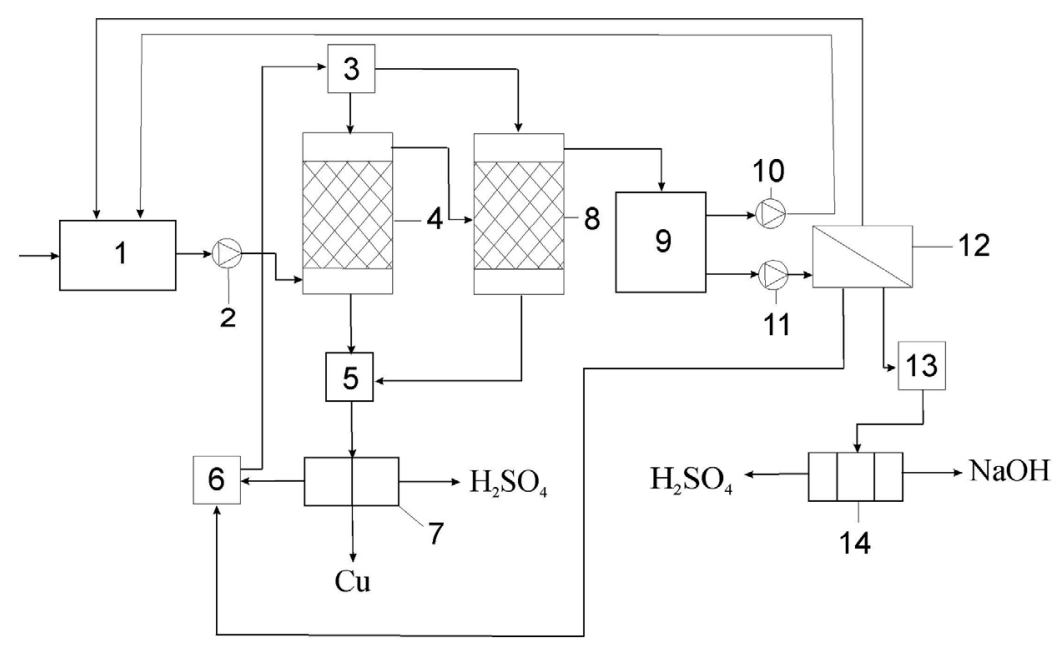

Figure 7. Schematic diagram of the extraction of heavy metal ions from the washing waters of the electroplating cycle using sulfate electrolytes: 1 - parts washing bath; 2, 10, 11 - pumps; 3, 6- sodium sulfate solution tanks; 4, 8 - cation exchange filters (cationite KU-2-8 in $\mathrm{Na}^{+}$form); 5 - the reservoir of the waste regeneration solution; 7, 14 - electrolyzers; 9 - purified water tank; 12 - reverse osmosis filter; 13 - concentrate tank. 
effective recovery of heavy metal cations from hydrochloric acid solutions simultaneously obtaining hydrochloric acid.

3. A technological scheme of a local plant for treatment of galvanic industry washing water containing metal cations, and solutions of sulfates of these metals used as the electrolytes was developed.

\section{REFERENCES}

1. Ayala-Bribiesca Erik, Pourcelly Gerald, Bazinet Laurent. 2007. Nature identification and morphology characterization of anion-exchange membrane fouling during conventional electrodialysis. J. Colloid and Interface Sci., 308 (1), 182-190.

2. Bairachnyi B.I., Borsuk O.M., Kovalenko Yu.I., Bairachny V.B. 2012. Sposib vyluchennia ioniv metaliv pidhrupy midi z tekhnohennykh vidkhodiv. Patenty i izobreteniya: Patenty, 74667. (in Ukrainian)

3. Chkhenadze N. V., Kurtskhalia Ts. S. 2004. K opredeleniyu dopustimoy velichiny kaltsievoy zhestkosti pri elektrodialize mineralizovannykh vod $\mathrm{s}$ odnovremennym kontsentrirovaniem. GEN: Georg. Eng. News., 4, 118-122. (in Russian)

4. Dzhalilov M.F. 1987. Povyshenie effektivnosti Hkationirovaniya vody. Khimiya i tekhnologiya vody, 9 (3), 252-255. (in Russian)

5. Faiziiev G.K., Nasirov A.M., Ibragimov K.D. and oth. I.c. USSR, IPC B $01 \mathrm{~J}$ 49/00. Methods of regeneration of the H-cation exchange filter of the first stage of chemical desalination of water. No. 4623872/26; applied 15.12.90; publ. 30.08.91., Bul. No. 32. (in Russian)

6. Feyziev G.K. 1988. Vysokoefektivnye metody umyagcheniya i opresneniya. Energoatomizdat, Moscow. (in Russian)

7. Fylypchuk V.L., Shatalov O.S. 2014. Devices for electrochemical wastewater treatment and safety of its operation. Komunalne Hospodarstvo Mist. Ser. Tekhnichni Nauky Ta Arkhitektury, 114, 147-150. (in Ukrainian)

8. Goltvianytska O.V., Shabliy T.O., Gomelya M.D. 2011. Getting the sulfuric acid and alkali solutions of sodium sulfate by electrodialysis method. Eastern-European Journal of Enterprise Technologies, 3/6(51), 18-22.

9. Goncharuk V.V., Chebotareva R.D., Bagriy V.A., Bashtan S.Yu., Remez S.V. 2005. Umyagchenie vody v elektrolizere s keramicheskoy membranoy. Khimiya i tekhnologiya vody, 27 (5), 460-470. (in Russian)

10. Grytsenko O.M., Gaiduk A.V., Bedlovska Kh.Ya., Gaidos I. 2016. Strukturni kharakterystyky khimichno vidnovlenoho nikeliu yak napovniuvacha polimernykh hidroheliv. Visnyk natsionalnoho universytetu «Lvivska politekhnika». Seriia «Khimiia, tekhnolohiia rechovyn ta yikh zastosuvannia», 351-357. (in Ukrainian)

11. Hodges Alastair McJodoe, Osvath Peter. Pat. 738488 Australia, IPC6 C02 F 001/42, B 01 J 049/00. Purification of a liquid stream. USF Filtration and Separations Group Inc. No. 199873247; applied 08.05.1998; publ. 20.09.2001.

12. Ivakina Ye.I., Zubets N.N., Lavrova Z.D. and oth. 1976. Pererabotka regenerata anionita EDE-10P v kislotu i shcheloch na opytnoy polupromyshlennoy elektroliznoy ustanovke. Teoriya i praktika sorbtsionnykh protsessov, 11, 92-95. (in Russian)

13. Melnyk L., Bessarab O., Matko S., Malyovanyy M. 2015. Adsorption of heavy metals ions from liquid media by palygorskite. Chemistry \& Chemical Technology, 9 (4), 467-470.

14. Mulder M. 1996. Basic principles of membrane technology. Springer Netherlands.

15. Obertas I.A. 2016. Some Theoretical Conditions for the Anodic Dissolution of Metal for the Filtration Method through the Materials with Redox Properties for Removal of Residual Aluminium of Drinking Water. Scientific Bulletin of UNFU of Ukraine, 26 (1), 264-267. (in Ukrainian)

16. Rohm and Haas Co., Tasaki Shintaro. Pat. 6060526 USA, IPC7 B $01 \mathrm{~J}$ 43/00. Mixed bed ion exchange resin system and methods of preparation. No. 09/226824; applied 07.01.99; publ. 09.05.00.

17. Shabliy T.A. 2010. Pererabotka otrabotannykh shchelochnykh i neytralnykh rastvorov ionoobmennogo umyagcheniya vody metodom eletroliza. Energotekhnologii i resursosberezhenie, 6. 63-66. (in Russian)

18. Shabliy T.O., Gomelia M.D., Panov E.M. 2010. Elekrokhimichna pererobka vidpratsovanykh rozchyniv, shcho utvoriuiutsia pry reheneratsii kationitiv. Ekologiya i promyshlennost, 2, 33-38.

19. Shabliy T.O., Gomelia M.D., Panov E.M. 2010. Vykorystannia elektrolizu $\mathrm{v}$ protsesi pererobky vidpratsovanykh reheneratsiinykh rozchyniv. Sbornik trudov XVIII Mezhdunarodnoy nauchnoprakticheskoy konferentsii «Ekologiya, energo- i resursosberezhenie, okhrana okruzhayushchey sredy i zdorove cheloveka, utilizatsiya otkhodov»,, Kharkov: Energostal, 181-184. (in Ukrainian)

20. Shabliy T., Goltvianytskaya E., Shabliy N. 2011. Electrochemical processing of regeneration solutions from ion-exchange treatment of water with production of acid and alkalis. Swedish - Polish Ukrainian cooperation project "Future urban sanitation to meet new requirements for water quality in the Baltic Sea region", Cracow, Poland.

21. Skira V.V., Tymofieiev I.L., Molchanov A.D., 
Karpinska I.A. 2004. Teoretychni umovy anodnoho rozdilennia metaliv metodom filtruvannia cherez zavantazhennia z okysno-vidnovnymy yakostiamy dlia vydalennia zalyshkovoho aliuminiiu z pytnoi vody. Bulletin of the National University «Lviv Polytechnic»: Chemistry, technology and applications of substances, 497, 125-127. (in Ukrainian)

22. Teel Paul A. Pat. 6783684 USA, IPC7 C02 F 1/42. Water softening apparatus and associated method for sensing depletion of salt in a brine tank. No. 09/957564; applied 20.09.2001; publ. 31.08 2004; NPC 210/687.

23. Trus I.M., Gomelia M.D., Radovechyk Ya.V. 2013.
Method of alkali solution concentration at electrochemical processing of eluates containing sodium salts. Eastern-European Journal of Enterprise Technologies, 5/6(65), 20-23. (in Ukrainian)

24. Trus I.M., Grabitchenko V.M., Gomelia M.D. 2013. Production of sulfuric acid during electrochemical processing of sulphate-containing eluates. Eastern-European Journal of Enterprise Technologies, 4/6(64), 10-13. (in Ukrainian)

25. Vasylenko L.O., Shumbar K.V. 2014. Ochyshchennia promyvnykh stichnykh vod halvanokoahuliatsiieiu. Mistobuduvannia ta terytorialne planuvannia, 51, 30-35. (in Ukrainian) 